\title{
EFEKTIVITAS PROMOSI KESEHATAN DALAM MENINGKATKAN SELF EFFICACY SISWA SMAN 2 TENTANG INFEKSI MENULAR SEKSUAL, HIV dan AIDS DI KOTA KUPANG
}

\author{
${ }^{1}$ Intje Picauly, ${ }^{2}$ Sabina Gero, ${ }^{3}$ Marthen R. Pellokila, ${ }^{4}$ Nadraeni P. Yakub \\ ${ }^{1}$ Program Studi Ilmu Kesehatan Masyarakat, FKM-Undana \\ ${ }^{2}$ Program Studi Keperawatan, Polketeks Kemenkes-Kupang \\ ${ }^{3}$ Jurusan Agribisnis, Fakultas Pertanian_Undana \\ ${ }^{4}$ Jurusan Keperawatan, Stikes Nusantara-Kupang
}

\begin{abstract}
ABSTRAK
$B$ esar risiko perilaku sosial dikalangan siswa SMA sehingga berpotensi tinggi menderita Infeksi Menular Seksual, HIV dan AIDS, sehingga sangat dibutuhkan informasi tentang kesehatan, penularan dan pencegahan penyakit kepada siswa SMA. Penelitian ini dilakukan untuk melihat apakah terdapat perubahan pengetahuan dan self efficacy siswa setelah mendapatkan promosi kesehatan yang diberikan melalui metode kelompok. Pendekatan kuantitatif dengan metode quasi experiment dan rancangan One Group Pretest Posttest. Populasi pada penelitian ini adalah semua siswa kelas 2 SMA Negeri 2 Kupang sebanyak 13 kelas dengan jumlah siswa 546 siswa. Sampel yang digunakan dengan cluster random sampling terhadap kelas yang memiliki pengetahuan yang rendah tentang IMS, HIV dan AIDS serta Self Efficacy. Analisa bivariat dalam penelitian ini dengan uji independent $T$ Test. Hasil analisis bivariat antara kelompok kecil dan kelompok besar dengan nilai $p$ value $(0,10)$ dimana hasil dari uji statistik tentang self efficacy terhadap IMS pada kelompok kecil diperoleh hasil dimana nilai $p$ value $(0,10)$ adalah 0,510 artinya self efficacy tentang IMS tidak ada perbedaan secara signifikan baik pada kelompok kecil maupun kelompok besar, sedangkan self efficacy terhadap HIV dan AIDS dimana dengan nilai $p$ value $(0,10)$ adalah 0,310 artinya self efficacy tentang HIV dan AIDS juga tidak ada perbedaan secara signifikan baik pada kelompok kecil dan kelompok besar. Uji statistik pada pengetahuan IMS dimana nilai $p$ value $(0,10)$ adalah 0,181 artinya pengetahuan siswa tentang IMS tidak ada perbedaan secara signifikan baik pada kelompok kecil maupun kelompok besar. Uji statistik pada pengetahuan HIV dan AIDS dimana nilai p value $(0,10)$ adalah 0,001 artinya pengetahuan siswa tentang HIV dan AIDS ada perbedaan secara signifikan baik pada kelompok kecil dan kelompok besar. Uji statistik pada promosi kesehatan terhadap IMS dimana nilai p value $(0,10)$ adalah 0,097 artinya promosi kesehatan yang diberikan ada perbedaan secara signifikan baik pada kelompok kecil maupun kelompok besar, sedangkan uji statistik pada promosi kesehatan tentang HIV dan AIDS hasil uji statistik dengan p value $(0,10)$ adalah 0,040 artinya promosi kesehatan yang diberikan ada perbedaan secara signifikan baik pada kelompok kecil maupun kelompok besar.
\end{abstract}

Kata Kunci: Self Efficacy, Efektivitas Promosi Kesehatan 


\title{
THE EFFECTIVENESS OF HEALTH PROMOTION IN INCREASING SELF EFFICACY OF THE STUDENTS AT SMAN 2 RELATED TO THE SEXUALLY TRANSMITTED INFECTIONS, HIV AND AIDS IN KUPANG AREA
}

\author{
${ }^{1}$ Intje Picauly, ${ }^{2}$ Sabina Gero, ${ }^{3}$ Marthen R. Pellokila, ${ }^{4}$ Nadraeni P. Yakub \\ ${ }^{1}$ Program Studi Ilmu Kesehatan Masyarakat, FKM-Undana \\ ${ }^{2}$ Program Studi Keperawatan, Polketeks Kemenkes-Kupang \\ ${ }^{3}$ Jurusan Agribisnis, Fakultas Pertanian_Undana \\ ${ }^{4}$ Jurusan Keperawatan, Stikes Nusantara-Kupang
}

\begin{abstract}
$T$

he risk of social behavior among high school students is high potential for STIs, HIV and AIDS, so that information on health, transmission and prevention of disease to high school students is urgently needed. This study was conducted to see whether there is a change of knowledge and self efficacy of students after getting health promotion given through group method. Quantitative approach with quasi experiment method and One Group Pretest Posttest design. The population in this study are all students of grade 2 SMA Negeri 2 Kupang as many as 13 classes with the number of students 546 students. Samples used with cluster random sampling of classes with low knowledge of STIs, HIV and AIDS and Self Efficacy. Bivariate analysis in this study with independent $T$ Test. The result of bivariate analysis between small group and large group with $p$ value $(0,10)$ where the result of statistical test about self efficacy to STI in small group obtained result where $p$ value value $(0,10)$ is 0,510 meaning self efficacy about IMS not There is a significant difference in both small groups and large groups, while self efficacy against HIV and AIDS where the value of p value (0.10) is 0.310 means that self efficacy about HIV and AIDS also no significant difference both in small groups and groups big. Statistical test on IMS knowledge where the value of $p$ value (0.10) is 0.181 means that students' knowledge about STIs there is no significant difference either in small groups or large groups. The statistical test on HIV and AIDS knowledge where p value (0.10) is 0.001 means that students' knowledge of HIV and AIDS is significantly different in both small groups and large groups. Statistic test on health promotion to STI where $p$ value $(0,10)$ is 0,097 meaning that health promotion given there is difference significantly both in small group and large group, while statistic test on health promotion about HIV and AIDS statistic test result with $p$ Value $(0,10)$ is 0,040 meaning that health promotion given there is significant difference either in small group or big group.
\end{abstract}

Keywords: Self Efficacy, Effectiveness of Health Promotion 


\section{PENDAHULUAN}

Data Komisi Penanggulangan AIDS (KPA) Kota Kupang yang didapat peneliti, untuk kasus IMS tahun 2016 secara keseluruhan berjumlah 2.338 kasus dimana dibagi berdasarkan jenis kelamin yaitu laki-laki sebanyak 415 kasus dan perempuan sebanyak 1.923 kasus. Kasus IMS sangat banyak dikarenakan adanya rujukan ulang dari kasus tersebut. Untuk kasus penderita HIV dan AIDS berdasarkan golongan usia dari tahun 2015, yaitu terdapat kasus pada usia < 4 tahun sebanyak 1 kasus, usia 20-24 tahun sebanyak 19 kasus, usia 25-49 tahun sebanyak 122 kasus dan usia > 50 tahun sebanyak 12 kasus. Tahun 2016 didapat data berdasarkan golongan usia, dimana usia $<4$ tahun sebanyak 6 kasus, usia 5-9 tahun sebanyak 1, usia 15-19 tahun sebanyak 4 kasus, usia 2024 tahun sebanyak 19 kasus, usia 25-49 tahun sebanyak 1167 kasus dan usia $>50$ tahun sebanyak 7 kasus. Bulan April 2017 didapat data menurut usia, usia $<4$ tahun sebanyak 1 kasus, usia 15-19 tahun sebanyak 2 kasus, usia 20-24 tahun sebanyak 5 kasus dan usia 2549 tahun sebanyak 59 kasus dan usia > 50 tahun sebanyak 2 kasus (KPA Kota, 2017)

Data-data yang didapat oleh peneliti demi menunjang penelitian pada kasus IMS, HIV dan AIDS dapat dilihat bahwa penderitanya setiap tahun semakin bertambah, walaupun dapat dilihat bahwa kasus HIV dan AIDS pada usia 15-19 tahun di Kota Kupang tidak sebanyak pada usia 25-49 tahun dan kasus IMS yang didapat pun terlihat sangat banyak. Kasus tersebut ibaratkan seperti gunung es yang hanya terlihat puncaknya sedangkan dasarnya yang tidak tampak sehingga sangat penting pemberian informasi tentang IMS, HIV dan AIDS dikalangan anak usia sekolah terutama untuk remaja. Hanya penderita yang sudah terinfeksi dan sadar akan pentingnya pemeriksaan HIV sehingga yang terlihat hanya beberapa penderita saja.

Penelitian terdahulu tentang Pengaruh Promosi Kesehatan Terhadap Pengetahuan Tentang Kanker Serviks dan Partisipasi Wanita Dalam Deteksi Dini Kanker Serviks di Puskesmas Bakunase promosi kesehatan yang diberikan dengan menggunakan media film. Setelah diberikan promosi kesehatan dengan menggunakan film, tingkat pengetahuan responden kelompok pertama menjadi lebih baik berkaitan dengan deteksi dini kanker ca serviks. Hal ini terbukti dengan jumlah responden yang berpengetahuan baik lebih besar dibandingkan dengan sebelum diberikan intervensi promosi kesehatan dengan media film. Jumlah responden yang berpengetahuan baik yakni sebanyak 35 orang $(68,6 \%)$, responden yang berpengetahuan cukup 14 orang (27,5\%). Responden yang berpengetahuan kurang yakni hanya sebanyak 2 orang. (Ivonny, 2015)

Hasil penelitian pada promosi kesehatan dengan menggunakan media leaflet kebanyakan responden kelompok kedua mempunyai pengetahuan yang kurang sebanyak 30 orang $(58,8 \%)$, sedangkan responden yang berpengetahuan baik sebanyak 5 orag $(9,8 \%)$. Setelah diberikan promosi kesehatan dengan leaflet tentang deteksi dini kanker ca serviks perubahannya tidak terlalu signifikan dimana responden yang berpengetahuan baik sebanyak 6 orang $(11,8 \%)$, responden yang berpengetahuan cukup sebanyak 21 orang $(41,2 \%)$ dan responden yang berpengetahuan kurang sebanyak 24 orang $(47,1 \%)$. (Ivonny, 2015)

Pengetahuan tentang kesehatan yang kurang dapat berdampak pada pergaulan dan perilaku yang salah, sehingga besar risiko perilaku sosial dikalangan siswa SMA dapat 
berpotensi tinggi menderita IMS, HIV dan AIDS. Oleh karena itu dengan dilakukannya pencegahan dan penanggulangan melalui pemberian promosi kesehatan tentang IMS, HIV dan AIDS dikalangan siswa SMA sangatlah penting. Berdasarkan penjelasan diatas peneliti bermaksud melakukan penelitian dengan metode kelompok melalui cara promosi kesehatan tentang IMS, HIV dan AIDS untuk siswa SMA.

\section{METODE PENELITIAN}

Metode penelitian yang digunakan adalah Quasi Experimen (rancangan eksperimen semu) karena desain ini tidak mempunyai pembatasan yang ketat terhadap randomisasi, dan pada saat yang sama dapat mengontrol ancaman-ancaman validitas. Dengan rancangan One Group Pretest Posttest. Populasi dalam penelitian ini adalah seluruh kelas 2 diSMA Negri 2 Kupang berjumlah 13 kelas perkelas terdapat 40 siswa atau total seluruh kelas 2 adalah 546 siswa. Teknik pengambilan sampel dalam penelitian ini adalah penarikan sample secara acak (cluster random sampling), Sampel yang diambil adalah dari kelas 2 di SMA Negeri 2 Kupang dengan pretest tentang IMS, HIV dan AIDS serta self efficacy menggunakan kuesioner kepada total populasi sebanyak 13 kelas (546 siswa), dari hasil pretest peneliti hanya akan mengambil responden yang memiliki pengetahuan kurang terhadap IMS, HIV dan AIDS sebanyak 146 siswa, dimana akan dibagi menjadi 2 kelompok, yaitu: kelompok besar dan kelompok kecil. Terdapat 2 kelompok besar berjumlah 40 siswa per kelompok dan 8 kelompok kecil berjumlah 10 siswa per kelempok. (Notoatmodjo, 2012)

\section{HASIL DAN PEMBAHASAN}

\section{Hasil}

Deskripsi Efektivitas Kelompok Kecil dan Kelompok Besar terhadap Variabel Dependen

\begin{tabular}{cccc}
\hline Variabel Dependent & Pembagian Kelompok & Nilai Mean & . Value \\
\hline Self Efficacy tentang IMS & Kelompok Kecil & 0,56 & 0,510 \\
& Kelompok Besar & 0,51 & \\
\hline Self Efficacy & Kelompok Kecil & 0,66 & 0,310 \\
Tentang HIV dan AIDS & Kelompok Besar & 0,58 & \\
\hline Pengetahuan IMS & Kelompok Kecil & 0,64 & 0,181 \\
& Kelompok Besar & 0,53 & 0,001 \\
\hline Pengetahuan HIV dan AIDS & Kelompok Kecil & 0,81 & \\
& Kelompok Besar & 0,56 & 0,097 \\
\hline Promosi Kesehatan & Kelompok Kecil & 0,63 & \\
Tentang IMS & Kelompok Besar & 0,49 & 0,040 \\
\hline Promosi Kesehatan tentang & Kelompok Kecil & 0,81 & \\
\hline
\end{tabular}

Tabel diatas menjelaskan bahwa hasil dari uji statistik tentang self efficacy terhadap IMS pada kelompok kecil diperoleh nilai $p$ value $(0,10)$ adalah 0,510 artinya self efficacy tentang IMS tidak ada perbedaan secara signifikan antara kelompok kecil dan kelompok besar. Selain itu self efficacy terhadap HIV dan AIDS hasil uji statistic diperoleh dimana nilai $p$ value $(0,10)$ adalah 0,310 artinya tidak ada perbedaan secara signifikan self efficacy tentang HIV dan AIDS antara kelompok kecil dan kelompok 
besar. Uji statistik pada pengetahuan IMS diperoleh dimana nilai $p$ value $(0,10)$ adalah 0,181 artinya tidak ada perbedaan secara signifikan pengetahuan siswa tentang IMS antara kelompok kecil maupun kelompok besar. Uji statistik pada pengetahuan HIV dan AIDS diperoleh dimana nilai $p$ value $(0,10)$ adalah 0,001 artinya pengetahuan siswa tentang HIV dan AIDS ada perbedaan secara signifikan antara kelompok kecil dan kelompok besar. Uji statistik pada promosi kesehatan terhadap IMS diperoleh dimana nilai $p$ value $(0,10)$ adalah 0,097 artinya promosi kesehatan yang diberikan ada perbedaan secara signifikan antara kelompok kecil dan kelompok besar, sedangkan uji statistik pada promosi kesehatan tentang HIV dan AIDS hasil uji statistik diperoleh dimana nilai dengan $p$ value $(0,10)$ adalah 0,040 artinya promosi kesehatan yang diberikan promosi kesehatan yang diberikan ada perbedaan secara signifikan antara kelompok kecil dan kelompok besar..

\section{Pembahasan}

Analisis bivariat dalam penelitian ini menggunakan uji Independent Sample T Test, dimana peneliti akan menguji beda pada metode promosi kesehatan yaitu metode kelompok besar dan kelompok kecil pada siswa kelas 2 SMA Negeri 2 Kupang dengan nilai signifikan $10 \%$.

1. Self Efficacy kelompok kecil dan kelompok besar

Hasil penelitian menunjukan bahwa keyakinan siswa dalam menilai kemampuan dirinya setelah menerima informasi melalui ceramah dan dengan media video dan leaflet sebagian besar responden yang tergabung dalam kategori baik tentang self efficacy pada IMS dalam kelompok kecil sebesar $41(28,1 \%)$ dan kelompok besar $37(25,3 \%)$, sedangkan self efficacy siswa tentang HIV dan AIDS dalam kategori baik pada kelompok kecil sebesar 48 (32,9\%) dan kelompok besar 42 (28,8\%) sudah memahami dengan benar tentang IMS, HIV dan AIDS. Hasil uji statistik tentang self efficacy terhadap IMS pada kelompok kecil diperoleh nilai mean 0,56 dan pada kelompok besar niliai mean 0,51 dapat disimpulkan bahwa ada perbedaan rata-rata antara kelompok kecil dan kelomopk besar, sedangkan hasil yang diperoleh dengan nilai $t_{\text {hitung }} 0,660<t_{\text {tabel }} 1,655$ dimana nilai $p$ value $(0,10)$ adalah 0,510 artinya self efficacy tentang IMS tidak ada perbedaan secara baik pada kelompok kecil dari pada kelompok besar. Hasil diatas tidak sejalan dengan penelitian yang dilakukan oleh Irfan (2014) mengatakan dalam penelitian ini berdasarkan uji korelasi yang telah dilakukan, diperoleh nilai korelasi sebesar 0,000 yang memiliki artian bahwa terdapat hubungan yang signifikan antara self efficacy dengan penyesuaian diri terhadap perguruan tinggi. Dapat dilihat bahwa koefisien korelasi pada penelitian ini adalah sebebesar 0, 467. Koefisien korelasi tersebut menunjukkan seberapa kuat hubungan yang dimiliki antara kedua variabel yang diuji. Penelitian lain oleh Handayani (2013) dimana teknik analisis data yang digunakan memakai analisis korelasi tata jenjang (Spearman Rank Order) dengan taraf signifikansi 0,05. Penelitian ini menghasilkan koefisien korelasi $(r=0,657)$ dengan $\mathrm{p}=0,000$, karena nilai signifikansinya lebih kecil dari tingkat kesalahan $(\mathrm{p}<0,05)$ maka hipotesis diterima. Hal ini berarti terdapat hubungan antara self efficacy dengan prestasi belajar siswa akselerasi.

Peneliti juga menilai self efficacy siswa tentang HIV dan AIDS dari hasil penelitian yang dilakukan peneliti mendapatkan nilai mean pada kelompok kecil 0,66 dan 
pada kelompok besar nilai mean 0,58 dapat disimpulkan bahwa ada perbedaaan rata-rata antara self efficacy siswa tentang HIV dan AIDS pada kelompok kecil dan kelompok besar, sedangkan hasil yang diperoleh dengan nilai $t$ hitung $1,018<t$ tabel 1,655 dimana dengan nilai $p$ value $(0,10)$ adalah 0,310 artinya tidak perbedaan secara ada signifikan self efficacy tentang HIV dan AIDS baik pada kelompok kecil maupun kelompok besar. Hasil analisis peneliti tidak sejalan dengan penelitian Purwanti (2016) dimana merupakan penelitian kuantitatif korelasi dengan subyek 24 siswa akselerasi. Hasil penelitian menunjukkan adanya hubungan antara self efficacy dengan flow akademik pada siswa akselerasi yang positif dan searah, artinya semakin tinggi self efficacy maka semakin tinggi flow akademik. Sementara teori Alwisol (2004) menjelaskan bahwa self efficacy adalah penilaian diri, apakah dapat melakukan tindakan yang baik atau buruk, tepat atau salah, dapat atau tidak dapat mengerjakan sesuai dengan yang dipersyaratkan. Menurut Bandura ( 1997) mengatakan bahwa adala faktor lain yang dapat mempengaruhi self efficacy salah satunya adalah persuasi social dimana informasi yang diberikan secara verbal oleh seseorang yang berpengaruh biasanya digunakan untuk meyakinkan seseorang cukup mampu melakukan suatu tugas. (Al- Maqassary, 2013)

Menurut peneliti self efficacy pada setiap individu akan meningkat jika didukung oleh pengetahuan yang diterima dan minat yang kuat berasal dari dalam diri sendiri tanpa ada paksaan dari lingkungan luar. Hasil penelitian menunjukan bahwa siswa pada kelompok kecil sebagian besar dapat mengetahui penyebab penularan IMS, tetapi pada materi tentang HIV dan AIDS yang diberikan oleh pemateri baik pada kelompok kecil maupun kelompok besar tidak mempengaruhi perubahan self efficacy siswa tentang HIV dan AIDS. Promosi kesehatan merupakan salah satu upaya yang dilakukan untuk merubah pandangan dan perilaku siswa tentang cara penularan dan pencegahan IMS, HIV dan AIDS. Hal ini menggambarkan bahwa pengetahuan siswa meningkat setelah mendapatkan materi tentang IMS, HIV dan AIDS. Dimana Siswa dapat menjawab pertanyaan dengan benar dalam mengukur kemampuan diri pada kuesioner yang diberikan. Namun masih ada sebagian kecil siswa masih ragu-ragu dengan pernyataan bahwa orang yang taat agama tidak akan tertular IMS, HIV dan AIDS serta makan bersama penderita IMS, HIV dan AIDS dapat menularkan penyakit tersebut. Ini mencerminkan nilai atau keyakinan yang dimiliki oleh siswa masih rendah oleh karena itu peran orang tua, guru dan kelompok peduli remaja sangat penting dalam melakukan pendampingan untuk memberikan informasi dari aspek spiritual dalam rangka mendekatkan diri dengan Tuhan untuk memperkaya nilai agama dalam pergaulan seharihari.

2. Pengetahuan IMS kelompok kecil dan kelompok besar

Hasil penelitian yang dilakukan peneliti pengetahuan siswa tentang IMS yang diberikan melalu ceramah dan video hasil jawaban yang diperoleh dari 73 responden pada kelompok kecil sebagian besar memahami dengan benar tentang penyakit IMS dengan kategori baik sebanyak 47 orang (32,2 \%). Sedangkan pada kelompok besar hasil jawaban yang diperoleh dari 73 responden sebagian besar kurang memahami dengan benar tentang penyakit IMS sebanyak 39 orang (26,7\%). Hasil uji statistik pada kelompok kecil diperoleh nilai mean 0,64 dan pada kempok besar niliai mean 0,53 dapat disimpulkan bahwa ada perbedaan rata-rata antara kelompok kecil dan kelompok besar dan hasil yang 
diperoleh dengan nilai $t_{\text {hitung }} 1,345<t_{\text {tabel }} 1,655$ dimana nilai $p$ value $(0,10)$ adalah 0,181 artinya tidak ada perbedaan secara signifikan pengetahuan siswa tentang IMS baik pada kelompok kecil maupun kelompok besar. Hasil ini sejalan dengan penelitian yang dilakukan oleh Wibowo (2013) dimana hasil analisis bivariat menunjukkan bahwa terdapat pengaruh promosi kesehatan baik metode audio visual dengan $p=0,00$, maupun metode buku saku dengan $\mathrm{p}=0,00$, terhadap peningkatan pengetahuan penggunaan MSG. Tidak terdapat perbedaan rerata antara kelompok perlakuan metode audio visual dan kelompok perlakuan metode buku saku dengan $\mathrm{p}=0,817$. Penelitian lain yang memiliki hasil berbeda dengan peneliti yaitu penelitian oleh Karundeng (2013) dengan metode pre eksperimental dengan pendekatan one group pre test-post test design menunjukan hasil penelitian teranalisis pengaruh pendidikan kesehatan terhadap tingkat pengetahuan dan sikap siswa SMA tentang penyakit menular seksual. Analisa bivariat dilakukan dengan menggunakan Wilcoxon Signed Rank Test dengan p value sikap=0,000 < =0,005. Ini menunjukkan bahwa ada pengaruh pemberian pendidikan kesehatan terhadap tingkat pengetahuan dan sikap siswa SMA tentang Penyakit Menular Seksual. Penelitian lain oleh Suci (2014) juga mengatakan Hasil penelitian mayoritas responden memiliki pengetahuan kurang tentang IMS yaitu sebanyak 36 orang $(53,7 \%)$, mayoritas responden di diagnosa positif menderita IMS yaitu sebanyak 51 orang $(76,1 \%)$. Dari hasil uji statistik dapat disimpulkan bahwa hipotesa ( $\mathrm{Ha}$ ) di terima yaitu ada hubungan yang signifikan antara pengetahuan dengan kejadian infeksi menular seksual di Klinik Mentari Puskesmas Panjang tahun 2014 dengan $p$ Value $=0,000<0,05$. Menurut teori Graffiths (1972) dalam Glanz (2008) dijelaskan bahwa upaya pendidikan kesehatan untuk menutup kesenjangan antara apa yang diketahui tentang praktek kesehatan yang optimal dan apa yang benar-benar dipraktikan. Sementara menurut (Simonds, 1976) dalam Glanz (2008) dijelaksan bahwa pendidikan kesehatan bertujuan sebagai perubahan perilaku kesehatan yang kondusif di masa depan.

Menurut peneliti pengetahuan akan IMS sangat diperlukan di berbagai kalangan terutama di kalangan remaja yang rentan dengan perilaku seks bebas. Hasil penelitian pada siswa kelas 2 SMA Negeri 2 Kupang menujukan bahwa sebagian besar siswa dapat menjawab dengan benar tentang cara penularan dan pencegahan IMS dan masih sedikit orang yang mempunyai pemahaman yang salah tentang IMS. Siswa yang tergabung dalam kelompok kecil sebagian besar dapat menangkap atau menyerap pesan yang disampaikan melalui ceramah dan video sedangkan pada kelompok besar masih sebagian kecil yang belum mememhami dengan benar tentang pengetahuan IMS. Pendidikan kesehatan perlu difokuskan pada kelompok kecil karena perhatian dan keseriusan dalam mengikuti ceramah lebih tinggi karena jumlah siswa hanya berjumlah 8-10 orang. Tingkat pemahaman atau penerimaan materi pada kelompok besar dinilai kurang efektif karena jumlah siswa terdiri dari 38-40 orang. Hal ini dapat mempengaruhi konsentrasi siswa dalam menerima pesan atau materi yang disampaikan, karena dalam satu kelompok mempunyai jumlah siswa yang besar dengan suasana yang kurang kondusif yang dapat mempengaruhi daya tangkap siswa tentang penyakit IMS. Pengetahuan yang kurang atau persepsi yang salah akan materi yang diberikan akan berpengaruh negative terhadap perilaku siswa dalam bertindak. Siswa bisa menyampaikan materi yang salah kepada teman-temannya tentang IMS, sehingga perlu direkomendasikan kepada TIM promosi 
kesehatan baik dari bidang kesehatan maupun dari sekolah, untuk lebih menggunakan metode yang mudah diterima oleh siswa.

3. Pengetahuan HIV dan ADIS kelompok kecil dan besar

Promosi kesehatan yang diberikan diharapkan dapat meningkatkan pengetahuan siswa tentang HIV dan AIDS. Hasil penelitian menunjukan bahwa sebagian besar siswa dalam kategori "baik" yang tergabung dalam kelompok kecil sebesar 59 (40,4\%) dan kelompok besar $41(28,1 \%)$ sudah memahami dengan benar tentang materi HIV dan AIDS. Hasil uji statistik pada kelompok kecil diperoleh nilai mean 0,81 dan pada kempok besar niliai mean 0,56 dapat disimpulkan bahwa ada perbedaan rata-rata antara kelompok kecil dan kelompok besar. Sedangkan hasil yang diperoleh dengan nilai $t$ hitung 3,303 $>t$ tabel 1,655 dimana nilai $\mathrm{p}$ value $(0,10)$ adalah 0,001 artinya pengetahuan siswa tentang HIV dan AIDS ada perbedaan secara signifikan baik pada kelompok kecil maupun kelompok besar. Hasil ini sejalan dengan penelitian Djou (2015) menunjukan Hasil penelitian ini menunjukkan ada hubungan antara pengetahuan, keyakinan, niat sikap, dan stigma dengan perilaku pencegahan penularan HIV dan AIDS, dengan signifikansi pengetahuan $(\mathrm{p}=0.025)$, keyakinan $(\mathrm{p}=0.049)$, niat $(\mathrm{p}=0.048)$, sikap $(\mathrm{p}=0.022)$, dan stigma $(\mathrm{p}=0.000)$ sedangkan variable niat dan stigma adalah paling berhubungan dengan model perilaku pencegahan penularan HIV dan AIDS pada gay dan waria di kota kupang. Penelitian lain oleh Simuningkalit (2010) mengatakan penelitian yang dilakukan dengan deskriptif potong lintang dimana hasilnya menjelaskan bahwa presentasi pengetahuan HIV dan AIDS dengan kategori baik pada siswa SMA perkotaan sekitar 54\% dan di pedesaan sekitar 46,6\%. Kategori baik pada siswa SMA dengan Pendidikan diatas SMP sebesar 58,6\% dan Pendidikan dibawah SMP 48,3\%. Sedangkan teori dijelaskan bahwa penularan penyakit HIV dan AIDS melalui hubungan seksual, kontak langsung dengan darah atau jarum suntik dan transmisi secara vertical dari ibu hamil pengidap HIV kepada bayinya melalui plasenta (Mansjoer, 2000). Sedangkan menurut Notoadmodjo (2007) dijelaskan bahwa pengetahuan merupakan hasil "tahu" dan ini terjadi setelah orang melakukan pengindraan terhadap suatu obyek tertentu.

Menurut peneliti siswa perlu mengetahui secara benar tentang penyebab, cara penularan dan pencegahan HIV dan AIDS sehingga siswa lebih waspada dalam pergaulan sehari-hari sesuai dengan norma dan nilai yang berlaku di masyarakat. Promosi kesehatan tentang HIV dan AIDS telah dilakukan di sekolah-sekolah namun masih sebagian besar siswa belum memahami dengan benar informasi yang diberikan yang terlihat dari hasil pre test yang menunjukan bahwa siswa masih ragu-ragu dengan pernyataan tentang materi HIV dan AIDS . Namun setelah mendengar materi tentang HIV dan AIDS melalui ceramah dan video sebagian besar siswa pada kelompok kecil dan kelompok besar mengetahui dengan benar tentang informasi HIV dan AIDS. Hal ini menunjukan bahwa siswa benar-benar mengikuti ceramah yang diberikan. Namun dengan strategi ini belum cukup untuk menyadarkan siswa akan penyakit HIV dan AIDS karena jika pengetahuan yang baik tidak diimbangi dengan kemauan dari dalam diri sendiri, tindakan atau perilaku yang baik maka kemungkinan untuk tertular penyakit HIV dan AIDS semakin tingggi. Oleh karena itu, bimbingan dan pendampingan dari orang tua dan para pendidik perlu ditingkatkan dalam menyadarkan remaja untuk berperilaku sesuai dengan nilai dan norma yang berlaku di masyarakat. Pendekatan spiritual dari tokoh agama perlu dialkukan secara 
rutin kepada kalangan remaja dalam rangka meningkatkan nilai spiritual remaja untuk mewujudkan tindakan nyata yang berguna bagi dirinya dan masa depan yang lebih baik.

4. Promosi Kesehatan kelompok kecil dan besar

Hasil penelitian promosi kesehatan yang diberikan melalui dengan metode kelompok kecil dan besar dimana media yang digunakan adalah video dan leaflet. Pemberian materi diselingi dengan sedikit ceramah tentang IMS oleh pemateri, sebagian besar responden berada dalam kategori baik sebesar 46 (31,5\%) yang tergolong dalam kelompok kecil dan 36 (24,7\%) dalam kelompok besar dimana menyatakan bahwa media yang digunakan oleh pemateri dapat membangkitkan minat siswa dalam memahami materi yang diberikan. Hasil uji statistik pada kelompok kecil nilai mean 0,63 dan kelompok besar diperoleh nilai mean 0,49 dapat disimpulkan bahwa ada perbedaan ratarata antara kelompok kecil dan kelompok besar. Hasil yang diperoleh dengan nilai $t$ hitung $1,672>t_{\text {tabel }} 1,655$ dimana nilai $\mathrm{p}$ value $(<0,10)$ adalah 0,097 artinya promosi kesehatan yang diberikan terdapat perbedaan secara signifikan baik pada kelompok kecil maupun kelompok besar. Hasil ini sejalan dengan penelitian Bertalina (2012) menunjukan bahwa penelitian ini menggunakan rancangan quasy eksperimen (Eksperimen Semu) dengan populasi siswa sekolah kelas 5 dengan jumlah sampel 79 orang. Pengumpulan data dengan menggunakan kuesioner dan kemudian diolah secara statistik: univariat dan bivariat dengan analisis uji $t$. Hasil penelitian menunjukkan, ada perbedaan yang signifikan antara nilai pengetahuan pada intervensi dengan menggunakan leaflet dengan $\mathrm{p}$ value 0,068 . Ada perbedaan yang signifikan antara nilai pengetahuan pada pengukuran pertama dan kedua yaitu pengukuran sebelum dan sesudah intervensi dengan ceramah/slide dengan $\mathrm{p}$ value 0,000 . Ada perbedaan yang signifikan rata-rata peningkatan pengetahuan antara siswa yang mendapat intervensi gizi seimbang dengan intervensi menggunakan leaflet dan ceramah/slide didapatkan nilai p 0,016. Penelitian lain yang dilakukan oleh Ardian (2015) menjelaskan bahwa Promosi kesehatan pada kelompok perlakuan (metode curah pendapat dan ceramah) mampu meningkatan pengetahuan ( $\mathrm{p}=$ 0,000). Promosi kesehatan pada kelompok kontrol (metode ceramah) mampu meningkatan pengetahuan $(\mathrm{p}=0,000)$. Ada perbedaan peningkatan pengetahuan HIV dan AIDS siswa sebelum dan setelah intervensi promosi kesehatan pada kelompok perlakuan dan kelompok kontrol $(\mathrm{p}=0,002)$ dengan selisih rata-rata nilai antara dua kelompok tersebut 3,55. Metode curah pendapat lebih efektif dalam meningkatkan pengetahuan. Sehingga terdapat pengaruh yang signifikan promosi kesehatan HIV dan AIDS melalui metode curah pendapat terhadap peningkatan pengetahuan pada remaja ( $\mathrm{p}$ value $0,000<0,05)$. Sedangkan teori promosi kesehatan adalah segala upaya yang direncanakan untuk mempengaruhi orang lain, baik individu, kelompok maupun masyarakat sehingga mereka melakukan apa yang diharapkan oleh pelaku Pendidikan atau promosi kesehatan (Notoatmodjo, 2012).

Peneliti juga melakukan promosi kesehatan tentang HIV dan AIDS dengan menggunakan media, teknik dan metode yang sama dengan promosi kesehatan tentang IMS. Hasil yang diperoleh sebagian besar responden tertarik dengan metode dan media yang digunakan dalam memberikan materi tentang HIV dan AIDS. Hasil uji statistik pada kelompok kecil diperoleh nilai mean 0,81 dan pada kelompok besar niliai mean 0,66 dapat disimpulkan bahwa ada perbedaan rata-rata antara promosi kesehatan tentang HIV 
dan AIDS pada kelompok kecil dan kelompok besar, sedangkan hasil yang diperoleh dengan nilai $t_{\text {hitung }} 2,074>t_{\text {tabel }} 1,655$ dimana nilai dengan $p$ value $(0,10)$ adalah 0,040 artinya promosi kesehatan yang diberikan terdapat perbedaan secara signifikan baik pada kelompok kecil maupun kelompok besar. Hasil ini sejalan dengan penelitian Rachmayanti (2013) yang menunjukan bahwa dalam metode kelompok buah dan sayur tentang perilaku cuci tangan di air mengalir terdapat perbedaan keterampilan sesudah dan sebelum perlakuan dengan hasil uji wilcoxom dengan nilai $\mathrm{p}=0,000$ dan wilcoxom and mannwitney dengan $\mathrm{p}=0,000$. Peneliti lain oleh Danthamrongkul (2016) mengatakan dilihat dari jenis kelamin baik pada responden laki-laki $(51,4 \%)$ dan perempuan $(48,6 \%)$. 90\% dari siswa mengetahui tentang HIV dan AIDS dari pengetahuan yang diterima dari televisi, radio dan internet $28 \%$ dan $24,5 \%$ mereka mengetahui dari pelatihan dan dari sekolah. Siswa mengetahui paket bantuan tentang test HIV tiap 2 kali setahun dan pengobatan gratis antiretroviral sebanyak 17\%. Pemahaman siswa laki-laki dalam pemakaian kondom demi mencegah siswa perempuan hamil $74 \%$. Teori tentang promosi kesehatan dijelaskan bahwa metode pendidikan kelompok harus diingat besarnya kelompok sasaran, serta tingkat pendidikan formal dan sasaran itu sendiri. Untuk kelompok yang besar metodenya akan lain dengan kelompok kecil. Efektifitas suatu metode tergantung pula pada besarnya sasaran pendidikan (Notoadmodjo, 2012).

Menurut peneliti promosi kesehatan yang disampaikan dalam kelompok akan membantu siswa lebih konsentrasi dalam menerima materi yang diberikan. Media yang digunakan harus menarik sehingga meningkatkan perhatian siswa untuk fokus pada materi yang diberikan. Hasil penelitian menunjukan bahwa sebagian siswa setuju dengan beberapa pernyaataan antara lain materi yang disampaikan menarik, dan media penyuluhan yang digunakan adalah leaflet dan video sehingga siswa mempunyai minat lebih banyak untuk mengetahui dan mencari informasi tentang IMS, HIV dan AIDS. Dapat dilihat bahwa semua siswa yang berada dalam kelompok kecil baik dalam pemberian materi IMS maupun materi HIV dan AIDS mereka lebih merasa bahwa pemberian materi dalam bentuk kelompok kecil lebih efektif dibandingkan pemberian materi dalam bentuk kelompok besar. Siswa pada kelompok kecil sebagian besar mempunyai ketertarikan lebih besar untuk mengetahui tentang IMS, HIV dan AIDS sedangkan siswa yang tergabung dalam kelompok besar kurang tertarik untuk mengikuti materi yang diberikan dikarenakan terlalu banyaknya jumlah kelompoknya, sehingga mempengaruhi konsetrasi antar siswa. Oleh karena itu, tim penyelenggara promosi kesehatan perlu merencenakan metode yang efektif dan menarik minat siswa dalam mengikuti materi yang diberikan.

\section{PENUTUP}

\section{SIMPULAN}

Berdasarkan hasil penelitian yang telah dilakukan dapat disimpulkan bahwa:

1. Self Efficaacy tentang IMS dengan menggunakan metode kelompok kecil dan besar dimana terdapat perbedaan antara dua metode yang digunakan serta hasil $t_{\text {hitung }} 0,660$ $<t_{\text {tabel }} 1,655$ dengan nilai signifikan yaitu 0,510>0,10. Self Efficacy tentang HIV dan AIDS dengan menggunakan metode kelompok kecil dan besar dimana terdapat 
perbedaan antara dua metode yang digunakan serta hasil $t_{\text {hitung }} 1,018<t_{\text {tabel }} 1,655$ dengan nilai signifikan yaitu $0,310>0,10$.

2. Promosi kesehatan tentang IMS dengan menggunakan metode kelompok kecil dan besar dimana terdapat perbedaan antara dua metode tersebut serta hasil thitung 1,672 > $t_{\text {tabel }} 1,655$ dengan memiliki nilai signifikan yaitu $0,097<0,10$. Promosi kesehatan tentang HIV dan AIDS dengan menggunakan metode kelompok kecil dan besar dimana terdapat perbedaan antara dua metode tersebut serta hasil $t_{\text {hitung }} 2,074>t_{\text {tabel }}$ 1,655 dengan memiliki nilai signifikan yaitu 0,040<0,10.

3. Pengetahuan tentang IMS dengan menggunakan metode kelompok kecil dan besar dimana terdapat perbedaan antara dua metode yang digunakan serta hasil $t_{\text {hitung }} 1,345$ $<t_{\text {tabel }} 1,655$ dengan nilai signifikan yaitu $0,181>0,10$.

4. Pengetahuan tentang HIV dan AIDS dengan menggunakan metode kelompok kecil dan besar dimana terdapat perbedaan antara dua metode yang digunakan serta hasil $t_{\text {hitung }} 3,303>t_{\text {tabel }} 1,655$ dengan nilai signifikan yaitu $0,001<0,10$.

\section{IMPLIKASI}

Promosi kesehatan dalam arti pendidikan, secara umum adalah segala upaya yang direncanakan untuk mempengaruhi orang lain, baik individu, kelompok, atau masyarakat, sehingga mereka melakukan apa yang diharapkan oleh pelaku pendidikan atau promosi kesehatan (Notoatmodjo, 2012) diharapkan dengan dilakukannya promosi kesehatan terhadap siswa SMA Negeri 2 Kupang, siswa dapat menerima materi dengan baik dan dapat mengaplikasikan dalam kehidupan sehari-hari maupun dalam lingkungan mereka.

Sangat penting dukungan dari keluarga maupun pihak sekolah dalam memberikan informasi tentang perilaku pergaulan remaja dan pengetahuan tentang IMS \& HIV dan AIDS. Selain itu, pihak sekolah juga dapat bekerja sama dengan Dinas Kesehatan ataupun Komisi Penanggulangan AIDS (KPA) dalam memberikan promosi kesehatan tentang IMS maupun HIV dan AIDS.

\section{DAFTAR PUSTAKA}

Al-Maqassary, A, 2013. Pengertian Self Efficacy. (http://www.ejurnal.com/2013/10/pengertian-self-efficacy.html) (diunduh 03 Januari 2017)

Ardian, I. Tsaqafannisa, M. 2015. Pengaruh Promosi Kesehatan Melalui Metode Curah Pendapat Terhadap Peningkatan Pengetahuan Remaja Tentang HIV dan AIDS. Nurscope Jurnal Keperawatan dan Pemikiran Ilmiah. 1 (6). 1-7 ISSN 24768987

Bertalina. 2012. Pengaruh Promosi Kesehatan Terhadap Peningkatan Pengetahuan Tentang Gizi Seimbang Pada Siswa Sekolah Dasar Negeri Di Kecamatan Rajabasa Kota Bandar Lampung. 58 Jurnal Kesehatan, Volume VI, Nomor 1, April 2015, hlm 56-63

Danhamrongkul, V., Voramongkol, N., Jangmongkol, S. 2016. Knowledge, Attitude and Behavior Related to HIV Infection of Extended School Student in Thailand. The 
16 $^{\text {th }}$ International Conference of Public Health Sciences. Publish by:Collage of Public Health Sciences, Chulalongkorn University

Djou, M, K. 2015. Analisis Faktor yang Behubungan dengan Perilaku Pencegahan Penulaan HIV dan AIDS Pada Gay dan Waria di Kota Kupang. Tesis Mahasiswa Prodi Ilmu Kesehatan Masyarakat, Pascasarjana UNDANA

Glanz, K., Rimer, B, K., Viswanath, K. 2008. Healt Behavior and Health Education: Theory, Research and Practice. $4^{\text {th }}$ Edition

Handayani, F. Nurwidawati, D. 2013. Hubungan Self Efficacy Dengan Prestasi Belajar Siswa Akselerasi. Character, Volume 01, Nomor 02 Tahun 2013

Irfan, M., Suprapti, V. 2013. Hubungan Self-Efficacy Dengan Penyesuaian Diri Terhadap Perguruan Tinggi Pada Mahasiswa Baru Fakultas Psikologi Universitas Airlangga. JURNAL Psikologi Pendidikan dan Perkembangan Volume 3, No. 3, Desember 2014

Ivonny, M,V. 2015. Pengetahuan Promosi Kesehatan Terhadap Pengetahuan Tentang Kanker Serviks dan Partisipasi Wanita dalam Deteksi Dini Kanker Serviks di Puskesmas Bakunase. Tesis Mahasiswa Prodi Ilmu Kesehatan Masyarakat, Pascasarjana UNDANA

Karundeng, S, R, M., Mamonto, S, F. 2013. Pengaruh Pendidikan Kesehatan Terhadap Tingkat Pengetahuandan Sikap Siswa SMA Tentang Penyakit Menular Seksual di SMK Fajar Bolang Mongondow Timur. Tesis Mahasiswa

Komisi Penanggualangan AIDS Kota Kupang. 2017. Data Penderita IMS, HIV dan AIDS di Kota Kupang tahun 2000-April 2017

Notoatmodjo, S. 2012. Promosi Kesehatan dan Ilmu Perilaku. Jakarta : PT Rineka Cipta

Notoatmodjo, S. 2012. Metodologi Penelitian Kesehatan. Jakarta: PT. Rineka Cipta

Purwanti, E. Akmallyah, M. 2016. Hubungan Antara Self Efficacy Dengan Flow Akademik Pada Siswa Akselerasi MP N 1 Sidoarjo. Psympathic, Jurnal Ilmiah Psikologi Desember 2016, Vol. 3, No. 2, Hal: 249 - 260

Rachmayanti, R, D. Penggunaan Media Panggung Boneka dalam Pendidikan Personal Hygiene Cuci Tangan Menggunakan Sabun di air Mengalir. Jurnal Promosi Kesehatan, Vol. 1, No. 1, Mei 2013: 1-9

Simanungkalit, S, B., Siswanto. 2010. Pengetahuan HIV dan AIDS Pada Siswa SMA di Indonesia.

Suci, A. Rihiantoro, T. Astuti, T. 2014 Hubungan Pengetahuan Wanita Pekerja Seksual Dengan Kejadian Infeksi Menular Seksual. Jurnal Keperawatan, Volume X, No. 2, Oktober 2014, ISSN 1907 - 0357

Wibowo, S. suryani, D. 2013. Pengaruh Promosi Kesehatan Metode Audio Visual Dan Metode Buku Saku Terhadap Peningkatan Pengetahuan Penggunaan Monosodium Glutamat (Msg) Pada Ibu Rumah Tangga. KESMAS, Vol.7, No.2, September 2013, Pp. 55 ISSN: 1978-0575 